Jerzy Norbert Grzegorek

E-MAIL: jerzygrzegorekpt@gmail.com orCID: 00oo-0oo1-7941-5601

\title{
Kultura taneczna osób z niepełnosprawnością. Metodyka czy animacja?
}

\begin{abstract}
STRESZCZENIE
Artykuł poświęcony jest kulturze tanecznej osób z niepełnosprawnością z perspektywy jej praktykowania. Może się ono ograniczać do działania wewnętrznego, jak i realizowania kreatywności tanecznej w ramach kultury artystycznej. Istotą staje się uzasadnienie doboru sposobów tego praktykowania oparego na cechach konstytutywnych tej kultury i ich poszczególnych wymiarach: teleologicznym, aksjologicznym, metodycznym i ewaluacyjnym.
\end{abstract}

SŁOWA KLUCZOWE: kultura taneczna, animacja, edukacja, idea pedagogiczna

\section{Wprowadzenie}

Taniec definiowany jako artystyczny środek wyrazu korzysta $\mathrm{z}$ ludzkiego ciała jak ze swoistego artefaktu - przedmiotu estetycznego (body art). Od początków tak intencjonalnego posługiwania się tańcem był on komponowany przez osoby pełnosprawne jedynie z myślą o osobach/tancerzach pełnosprawnych (zob. Grzegorek, 2015, s. 96-101). Celem lepszego uchwycenia tej perspektywy odwołam się jedynie do dwóch - wydawałoby się - odległych od siebie na kontinuum temporalno-historycznym kontekstów edukacyjno-wychowawczych. To one, na tle pokoleniowym systematycznie stabilizowały naszą wrażliwość estetyczną kształtując sposoby postrzegania dziedzin artystycznych w obrębie sztuki ciała. Równocześnie nadawały granice naszej refleksji mieszczącej się w krytyce artystyczno-estetycznej, dookreślając normy i reguły kwalifikacyjne wszelkim manifestacjom podmiotowym czynionym w ramach kultury artystycznej - w szczególności na starym kontynencie. Platon pisał o tym w następujących słowach:

Dobry wygląd i piękny rytm towarzyszą prostocie duszy. Brzydki wygląd i brak rytmu, i brak harmonii to zjawiska bliźniacze, spokrewnione ze złym wysłowieniem i złym charakterem (1958, s. 159-160);

a tak rozpatrywał to - współcześnie - Roman Ingarden 
jeżeli nasze dzieła są wysokowartościowe, piękne, duchowo bogate, szlachetne i mądre, my sami przez nie dobrzejemy, a jeśli niosą w sobie ślady zła, szpetoty i niemocy, choroby lub obłędu, stajemy się pod ich wpływem gorsi, ubożsi, słabsi lub chorzy (Ingarden, 1972, s. 36).

Powszechnie przyjęta artykulacja tego, co należy uważać za estetycznie słuszne, godne i właściwe, w tanecznej działalności artystycznej sprawiło, że współcześnie jedynie nieliczni, a wyróżniający się konsekwencją pracy tancerze (nie)pełnosprawni ${ }^{1}$ stają się artystami rozpoznawalnymi na równi z twórcami (pełno)sprawnymi. Pracując świadomie, głównie na gruncie współczesnego body art'u, opierając się na swoistości kreacji artystycznych manifestacji z intencjonalnym wykorzystywaniem idiomów ruchu i rytmu tancerze $\mathrm{z}$ niepełnosprawnością wpisują się w ogólnie obowiązujące normy i reguły sztuki tańca - nadal jednak balansując na pograniczu tego, co społecznie i kulturowo uważne jest za normę.

Celem niniejszego opracowania, będącego jednocześnie częścią cyklu opracowań inicjujących naukową dyskusję na temat kultury tanecznej osób z niepełnosprawnością (Grzegorek, 2015, s. 101-102; 2016, s. 135; 2019b, s. 58-59; 2020, s. 55-74.) jest propozycja wskazania kierunków i sposobów jej twórczego praktykowania $z$ wykorzystywaniem idiomów ruchu i rytmu tancerzy (nie?)pełnosprawnych. Wymaga to równoczesnego doprecyzowania poszczególnych wymiarów: teleologicznego, aksjologicznego, metodycznego i ewaluacyjnego owych kierunków i sposobów, jakie wynikają z idei i cech konstytutywnych kultury tanecznej osób z niepełnosprawnością.

\section{Kultura taneczna osób z niepełnosprawnością jako cel, a nie środek}

Proponowana przeze mnie definicja kultury tanecznej osób z niepełnosprawnością

wyraża się przez zespół wartości i wzorów odnoszących się do zachowań tanecznych osób z niepełnosprawnością, praktykowanych i uznawanych za własne wraz z tymi zachowaniami. Kulturę taneczną osób z niepełnosprawnością tworzy ogół

1 W niniejszym opracowaniu dokonuję celowego zabiegu $\mathrm{w}$ następującej pisowni: (nie)pełnosprawny, (nie?)pełnosprawny, pełnosprawny, (pełno)sprawny zmierzając ku (auto)refleksji pedagogicznej. Pomimo osobistego usytuowania poznawczego - jako stale poszukujący badacz - nie czynię ostatecznych rozstrzygnięć na temat społecznego, w tym indywidualnego dookreślania realizowanej działalności tanecznej przez osoby niepełnosprawne. Rozstrzygnięcia bowiem stale się formułują, podlegając spiralnie nawracającej ewaluacji, także w ramach realizowanych przeze mnie badań. Materia tu poruszana jest niezwykle wrażliwa i oporna na zmiany. Tekst ów ma zatem stanowić zarówno dyskusję autora z czytelnikiem, jak i samym sobą. Wspomniany zabieg pisarski z wykorzystaniem nawiasu ma stanowić istotny zamysł nad tym: jak jest(?), jak może być(?), jak zmieniać(?) i czy Twoim/moim zdaniem należy dokonywać zmiany obecnego stanu rzeczy(?). 
zachowań tanecznych, w jakiejś części odmiennych od ogólnie przestrzeganych norm, w tym kwalifikacyjnych i kulturowych w wyniku braku częściowej lub pełnej możliwości sprostania im. Dziedziny kultury tanecznej osób z niepełnosprawnością stanowić będą swoiste okazje do tańczenia, dobór muzyki i formy tańca, repertuar taneczny oraz funkcje tańca (Grzegorek, 2019, s. 64; 2020).

W jej założeniu mieści się uwzględnienie i dookreślenie zarówno grupowych, jak i indywidualnych potencjałów kreatywności tanecznej osób z niepełnosprawnością inicjujących swoistą praktykę kulturową w oparciu o niepowtarzalność idiomów ruchu i rytmu. Pozwala to na wykraczanie poza sferę odtwórczą, naśladowczą, terapeutyczną i wspierającą, wpisując ową praktykę artystyczną w przestrzeń autonomicznej i suwerennej działalności kulturowej, w tym w obszar tej aktywności, która pozwoliłaby na rozszerzenie obowiązujących zasobów społecznie akceptowanych norm i reguł kwalifikacyjnych w kulturze artystycznej.

Osoby $\mathrm{z}$ niepełnosprawnością posługujące się w kreatywności tanecznej swoistymi idiomami ruchu i rytmu, a zatem indywidualnymi zasobami „określonych” znaków i symboli artystycznego wyrazu mogą tworzyć - odwołując się do koncepcji Antoniny Kłoskowskiej - „określoną” strukturę ich społecznego wytwarzania (1981, s. 129-215). Przyjęcie takiej perspektywy posiada dualny wymiar, ponieważ dzięki posługiwaniu się własnym zasobem znaków i symboli tancerze (nie?)pełnosprawni:

- mogą dokonywać ich interpretacji zgodnie z rozumieniem przyjętych przez siebie kryteriów autoteliczności i symboliczności w ramach układu kultury symbolicznej, a równocześnie,

- stawać się jej autonomiczną i pełnoprawną częścią.

Kultura taneczna osób z niepełnosprawnością może zmierzać w stronę swoistego „przejścia” w stronę kultury własnej, spełniając „określone” funkcje społeczno-kulturowe przez tworzenie rozpoznawalnego i konstytuującego się zasobu norm i reguł kwalifikacyjnych.

Nie uwzględniając w niniejszej dyskusji sfery odtwórczej, naśladowczej, terapeutycznej i wspierającej, kultura ta może opierać się na dwóch podstawowych kierunkach i sposobach jej praktykowania. Pierwszy, sprowadzać się będzie do praktykowania „wewnętrznego”, a zatem podejmowania aktywności twórczej i odbiorczej jedynie we własnym kręgu kulturowym. W zasadniczy sposób będzie to jednak ograniczać możliwości zaistnienia szerszej komunikacji, w tym wymiany i przenikania, powodując schematyczny zastój w materii, a nawet blokadę jej ewolucji. Z kolei drugi, kierować 
może podejmowane przez osoby z niepełnosprawnością działania i ich treści w stronę kultury artystycznej. Zaistnieje wówczas swoiste przeniesienie ich w obszar pogranicza dziedzinowego sprzyjając przenikaniu znaków i symboli. Poddawane transpozycji równocześnie same mogą inicjować zmiany w obszarze obowiązujących i społecznie akceptowalnych reguł i norm kwalifikacyjnych. Kulturę artystyczną - co uzasadnia Teresa Kostyrko - należy przy tym rozumieć jako manifestacje podmiotowe (Kmita i Kostyrko, 1983, s. 126). W jej ramach mieszczą się wszelkie wytwory artystyczne, programy artystyczne i estetyczne realizowane przez grupy twórcze. Dodajmy, że jest to również znaczący obszar krytyki artystycznej i wyrażania przekonań werbalizowanych przez artystów, krytyków i odbiorców. Artystyczne manifestacje podmiotowe stanowią zatem rezultat zastosowanych reguł i norm w procesie twórczym lub odbiorczym, a obowiązujących w sztuce. Nie należy przy tym mylić sztuki i kultury artystycznej. Sztukę tworzą bowiem przyjęte i akceptowalne społecznie normy kwalifikacyjne, które wyznaczają granice postrzegania i rozumienia wartości artystycznych i estetycznych wraz z regułami, które dookreślają sposoby ich realizacji. Kulturę artystyczną będziemy zatem rozpatrywali znacznie szerzej niż sztukę mając na uwadze zarówno normy, których realizacja jest wystarczająca i niezbędna do uzyskania dzieła sztuki jak i zespoły norm, których realizacja jest tu niewystarczająca.

Kultura taneczna osób $\mathrm{z}$ niepełnosprawnością stając się kulturą artystyczną stanowić będzie - przytaczając słowa Antoniny Kłoskowskiej - określone i racjonalne działania (1981, s. 129-215). Z kolei praktyka artystyczna regulowana będzie przez „grupową świadomość artystyczną” (Kostyrko, 1985, s. 27). Oznacza to, że jej strukturę, prócz kompetencji i reguł kulturowych dookreślać będzie przede wszystkim doświadczenie artystów oraz wiedza artystyczna na gruncie społecznym. By uznać owe działania za wpisujące kulturę taneczną osób z niepełnosprawnością w ogólnie akceptowalne normy i reguły kwalifikacyjne, należy przyjąć proponowane cechy konstytutywne dookreślające: (1) rozumienie kultury tanecznej osób z niepełnosprawnością jako kultury własnej; (2) traktowania specyfiki ruchu i rytmu osób z niepełnosprawnością jako idiomatu tańca; (3) traktowania idiomatu tańca osób z niepełnosprawnością jako zasadniczego przedmiotu oddziaływań kulturowych i edukacyjnych; (4) przyjęcia prospektywnych, proosobowych i prohumanistycznych oddziaływań kultury tanecznej osób z niepełnosprawnością jako niezbędnego warunku postrzegania jej jako idei pedagogicznej. 


\section{Metodyka, czyli jednak poziom stabilności}

Taniec stanowi wielopłaszczyznowy obszar badań. Nie sposób w kilku zdaniach przedstawić liczebności i różnorodności jego definicji. Są one rozpatrywane - co uwypuklił Rodryk Lange (2000) - z perspektywy: prymitywnych instynktów w ujęciu Aleksandra Bella Filsona Younga jako: „uniwersalny ludzki środek wyrazu, poprzez ruchy kończyn i całego ciała, z poczuciem rytmu, które jest zakorzenione pośród prymitywnych instynktów świata zwierzęcego" (s. 34); sztuki, w rozważaniach Diderota stwierdzającego, że „Taniec jest $\mathrm{w}$ gruncie rzeczy pewnego rodzaju poezją. Jako taki winien się on posługiwać swymi własnymi środkami wyrazu" (s. 23); emocji, co odnajdujemy w Encyclopedia Britannica z lat 1768-1771 w definicji tańca określanego: „przyjemnym ruchem ciała, przystosowanym przez sztukę do taktu lub melodii instrumentów, lub też głosu. Tańczenie jest zwykle rezultatem i wyrazem radości” (s. 24); fizjologii, jak czynił to Herbert Spancer twierdząc, że „Ogólnie biorąc ruchy mięśni są powodowane emocjami w szerokim tego słowa znaczeniu” (s. 36), psychiki człowieka, co starał się uwydatnić Johan Schikowski twierdząc, że „wyłonił się w obliczu potrzeby rozładowania napięć psychicznych za pomocą rytmicznego ruchu" (s. 37); historyczno-dedukcyjnej za Maxem v. Boehnem wskazującym, że „Taniec wywodzi się z emocjonalnego impulsu i improwizacji” (s. 36); aż po współczesne definiowanie o charakterze metodyczno-synchronicznym, na co wskazał Camill $\mathrm{H}$. Wedgwood wpisując ruch i rytm w określoną strukturę, ponieważ: „Tańczenie polega na rytmicznych ruchach całego ciała lub jego części, zgodnie z pewnym schematem indywidualnej lub grupowej akcji, wyrażającej emocje lub myśli” (s. 37).

Ostatnia z przytaczanych za Roderykiem Lange definicji wydaje się być najbardziej adekwatna $\mathrm{w}$ naszych rozważaniach, zawierając równocześnie istotę treści z pozostałych definicji i sformułowań. Interesując nas, a wskazywany w niej „schemat” należy odnieść bezpośrednio do kreślonego normami i regułami stylu tańca. Zasadniczo każdy współcześnie wykorzystywany styl taneczny - począwszy od towarzyskiego, sportowego, klasycznego, ludowego, współczesnego, nowoczesnego, jazzu, hip-hopu, streetdance, a na technice improwizacji kontaktowej (Contact improvisation) kończąc - posiada swoisty schemat, idiom, dookreślający zakres ruchu i rytmu obowiązującej metodyki jego nauczania. Termin metodyka - jak uzasadnia Władysław Kopaliński - odnosi się do „zbioru/zbiorów zasad, sposobów wykonywania określonej pracy; osiągnięcia określonego celu; szczegółowe normy postępowania właściwe danej nauce; (metodzie nauczania) dydaktyka szczegółowa (2000, s. 326). Metodyka nauczania tańca oznacza zatem stabilność posługiwania się zrozumiałym i powszechnie rozpoznawalnym zasobem znaków i symboli 
odpowiadających przyjętym i ogólnie akceptowanym zespołom norm i reguł kwalifikacyjnych $\mathrm{w}$ tej dziedzinie sztuki. Wiąże się to z fizjologią ludzkiego ciała, a zatem przyjęciem określonego i stabilnego wzorca, który - przy ogólnej akceptacji - stanowi zdefiniowany (pełno)sprawnością zasób ruchu i jego rytmu, jaki winien zachodzić w trakcie rytmicznej akcji tanecznej wokół poszczególnych osi i płaszczyzn ciała tancerza/tancerzy.

\section{Od metodyki w stronę animacji, czyli różnica na poziomie (de?)stabilizacji}

W rozważaniach nad kierunkami i sposobami praktykowania tańca przez osoby z niepełnosprawnością należy pochylić się nad ustaleniem różnicy, jaka występuje między metodyką a działaniem i jego treścią. Metodyka tańca, w stabilnych warunkach, to znaczy takich, w których tancerz posiada możliwość (fizyczną i psychiczną) posługiwania się zrozumiałym i powszechnie rozpoznawalnym zasobem znaków i symboli, co odpowiada przyjętym i ogólnie akceptowalnym zespołom norm i reguł kwalifikacyjnych opiera się na związku wymiany między tancerzem a nauczycielem/instruktorem. Jest to równocześnie związek - zależności przeżywanej - w określonym otoczeniu, a zatem miejscu i atmosferze jego kultury (sala prób, prywatna szkoła tańca, uczelnia artystyczna, dom kultury, ulica i inne).

Tancerz pełnosprawny wyraża się przez język, tj. zespół znaków i symboli przynależny określonemu stylowi tańca. Jest zatem w stanie odpowiadać na polecenia/zadania nauczyciela/instruktora operującego tożsamym zasobem zgodnie z ogólnie przyjętym trybem kolejności i poszczególnych etapów nauczania. $\mathrm{W}$ przypadku osób $\mathrm{z}$ niepełnosprawnością praca artystyczna w zakresie tak rozumianej metodyki staje się to trudna, a nawet praktycznie niemożliwa do zrealizowania. Osoby z niepełnosprawnością charakteryzują się swoistością zakresów ruchu i jego rytmu, który należy traktować jako indywidualny idiom (Grzegorek, 2019b; 2020). Podkreślmy, że ów idiom należy traktować - podobnie ujęciu lingwistycznemu - jako „związek wyrazowy właściwy tylko danemu językowi, nieprzetłumaczalny dosłownie na inny język (Kopaliński, 200o, s. 221). Nauczyciele/instruktorzy podejmując się - nauczania tańca osoby z niepełnosprawnością, w zgodzie z metodyką odpowiadającą określonemu stylowi, wpisują się najczęściej w „Związek wymiany", który parafrazuje Héléne Gratiot-Alphandery wodniesieniu do kultury szkoły „w której dziecko odpowiada na pobudzanie dorosłego”. Szkoła staje się wówczas miejscem „w którym niemi mówią do głuchych”. Dlatego należy - zdaniem autorki - oddać głos dziecku, by być pod wpływem jego języka, a zatem sposobów swoistego wyrażania się - przy czym język ten 
jest szeroko rozumiany (Gratiot-Alphandery, 1977, s. 1-2; za: Żebrowski, 1987, s. 14). Przychylam się do tego, by uznać powyższe za założenie podstawowe $\mathrm{w}$ pracy z tancerzami (nie?)pełnosprawnymi, która opierać się będzie na działaniu zmierzającym do wyzwalania ich kreatywności tanecznej opartej na niepowtarzalności idiomów ruchu i jego rytmu, jakimi dysponują. Takie usytuowanie uwydatnia potrzebę odwrócenia dominanty w relacji - instytucja-miejsce/nauczyciel-instruktor-metodyka a tancerze $\mathrm{z}$ niepełnosprawnością. Skierowanie się w stronę źródła działania stawiając je za cel, a nie środek pozwoli na to, by to osoby z niepełnosprawnością mogły samodzielnie stanowić o doborze treści, form oraz sposobów ich realizacji, dookreślając rozumienie tak powstającej kultury tanecznej jako kultury własnej. Chodzi bowiem nie o przekazywanie, kształtowanie, wyuczanie czy nauczanie, a ożywianie, inspirowanie do odkrywania sprawności i nadawania jej swoistej formy posługiwania się własnym językiem ruchu i rytmu ciała, co może zainicjować kreatywne poszerzanie jego zasobów i zakresów. Temu sprzyja idea animacji. Ona bowiem narusza schemat wykluczenia mniejszości z niesprawiedliwie przyjętych przez większość warunków stabilności norm i reguł kwalifikacyjnych kierując jednych i drugich w stronę pozytywnej zmiany - co odpowiada wymiarowi teleologicznemu rozpatrywanych tu kierunków praktyki tanecznej.

\section{Animacja kultury tanecznej osób z niepełnosprawnością, czyli w stronę tancerza (pełno)sprawnego}

Źródłosłów pojęcia „animacja” wywodzi się od łacińskich słów: anima - dusza i animare - 'obdarzyć duszą', 'powołać do życia' (Kopczyńska, 1993). Animacja jest działaniem wnoszącym żywotność, poruszającym uczucia, wzmacnianiem sił, podnoszeniem życia na wyższy poziom, rozpoczynaniem określonego przedsięwzięcia, ożywianiem zespołu osób, w którym przeobrażenia nie następują spontanicznie lub są utrudniane i blokowane uwarunkowaniami społecznymi (Żebrowski, 1987, s. 29-30). Henry Thery stwierdził, że animację implikują trzy ściśle ze sobą powiązane procesy: 1) proces odkrywania potencjałów; 2) proces organizowania związków i 3) proces twórczy. Pierwszy z nich polega na tworzeniu warunków do tego, aby zarówno grupa, jak i osoba mogły odkryć i zrozumieć tkwiące w nich potrzeby, problemy, wątpliwości, pragnienia i umiejętności. Drugi opiera się na organizowaniu stosunków, kształtowaniu kontaktów między ludźmi oraz ludzi z wytworami/ dziełami kultury i ich twórcami. U podstaw tych związków leży wzajemne zrozumienie i porozumienie, opierające się na akceptacji. Trzeci z procesów stanowi inicjowanie twórczości, ujawniającej się dzięki sprzęganiu umie- 
jętności jednostek i grup z ich otoczeniem poprzez ekspresję, inicjatywę, odpowiedzialność i działania innowacyjne (Besnard, 1988, s. 345). Animacja wraz z uwzględnieniem w pracy artystycznej tancerzy (nie?)pełnosprawnych choćby jednego $\mathrm{z}$ trzech powyższych procesów będzie działaniem o charakterze partycypacyjnym. Związek wymiany obejmie relację animatora i tancerza, w której ten pierwszy stanie w obliczu konieczności zrozumienia odmiennych zasad ruchu i jego rytmu, co posiada wartość dydaktyczną i edukacyjną, ale także i wychowawczą, i samokształtującą. Stanie się to tym bardziej racjonalne - jak podkreślił Jan Szczepański - „ponieważ poznanie i zrozumienie Innego człowieka tworzy siebie $\mathrm{w}$ relacji $\mathrm{z}$ nim, to zaś ułatwia zrozumienie jego i siebie (1980, s. 82-83). Tylko wówczas będzie to autentycznie żywa relacja opierająca się na wzajemnym odkrywaniu potencjałów twórczych (np. w usytuowaniu choreografa i tancerza) i racjonalnej wymianie kompetencji oraz zasobów wiedzy, co odpowiada wymiarowi metodycznemu. Tak realizowana praktyka we wzajemności uczenia się sprzyja mobilizowaniu do podejmowania działań innowacyjnych, a przede wszystkim dostrzegania potrzeby wydobywania się z tkwienia w sferze odtwórczo-naśladowczej. Akceptowane, wspierane i świadomie realizowane działania artystyczne stanowić mogą - korzystając ze słów Janusza Gajdy - „bardziej spontaniczny i twórczy udział poszczególnych osób w odbieraniu, przyswajaniu, a także tworzeniu kultury w zależności od akceptowanych i wyznawanych wartości, co prowadzi (...) do utwierdzania i wzbogacania ich tożsamości kulturalnej" (Gajda, 1993a, s. 7). Prezentowany przeze mnie kierunek refleksji nad animacją kultury tanecznej osób z niepełnosprawnością odpowiada zasadzie przyjętej przez Annę Mioduszewską za francuskimi teoretykami mówiącej, że najważniejszym staje się: „przede wszystkim inspirowanie twórczości w miejsce powtarzania i wynalazczości zamiast imitacji. Trzeba pamiętać, że dużo łatwiej jest mówić o twórczości niż ją rzeczywiście rozbudzać” (1979, s. 155).

Zdaniem francuskich teoretyków głównym zadaniem animacji jest pomoc w nauczeniu się wspólnej pracy. Podstawą jest tu umiejętność wyznaczania celów. Do tego potrzebna jest otwartość i refleksja nad światem, a równocześnie wyrobienie sobie poglądu na świat oraz sposobów dostrzegania związków między człowiekiem a światem (Żebrowski, 1987, s. 13). To ujęcie pozwala na ożywczy udział animatorów w kreatywnym wykorzystywaniu specyfiki idiomu ruchu i rytmu przez osoby z niepełnosprawnością stając się mediatorem w sferze komunikacyjnej na polu kultury artystycznej. Anna Mioduszewska podkreśliła dostrzegany przez teoretyków francuskich potencjał animacji, jakim jest pośredniczenie w komunikacji sprzyjając jej ułatwianiu 
- przynajmniej w dwóch zasadniczych dla niniejszych rozważań zakresach. Zachodzi bowiem:

- między przekazem a odbiorcą: odszyfrowując przekaz, tłumaczy go na język odbiorcy, ułatwia jego przyjęcie lub odrzucenie;

- między samymi odbiorcami: stwarza środowisko odbiorców, pomagając im w określeniu swoich problemów i szukaniu sposobów ich rozwiązania (1979, s. 155).

Dzięki temu animacja jako działanie i animator jako mediator może sprzyjać postrzeganiu kreatywności tanecznej osób z niepełnosprawnością jako zasadniczego przedmiotu oddziaływań kulturowych i edukacyjnych zarówno na polu wewnętrznego praktykowania przez nich tańca jak i przekraczania granic kreowania komunikacji w szerszym społeczno-kulturowym zakresie. Temu służyć mogą wytwory tej kultury w postaci artystycznych manifestacji - poddawane pod krytykę na gruncie kultury artystycznej. W obu przypadkach osoba $\mathrm{z}$ niepełnosprawnością praktykująca taniec będzie mogła być postrzegana jako pełnoprawny artysta - tancerz (pełno)sprawny, co uzasadnił Florian Znaniecki pisząc tak:

każdy, kto w jakimś kręgu społecznym jest uważany za artystę i sam się za takiego uważa, spełniając odnośną rolę ku zadowoleniu uczestników tego kręgu, musi być obiektywnie zaliczony do kategorii artystów, bez względu na to, czy jego twory stanowią lub nie samodzielny przyczynek w danej dziedzinie sztuki i jaką wartość przypisze im krytyk z punktu widzenia takich lub innych sprawdzianów estetycznych (Znaniecki, 1937, s. 507).

Praktyka kultury tanecznej osób z niepełnosprawnością rozpatrywana z udziałem animacji stanowi - co staram się wykazać - znacznie szerszą perspektywę rozwoju osobowego, społecznego i kulturowego. Działanie animacyjne skupiając się na tancerzu i jego potencjale twórczym jako na człowieku - nie tylko potrzebującym zrozumienia, ale także chcącym zrozumieć samego siebie przez sztukę - staje się ideą opartą na inicjowaniu racjonalności komunikacyjnej i emancypacji kształtując szeroko rozumianą przestrzeń szacunku wobec wartości indywidualnych i zbiorowych - co odpowiada wymiarowi aksjologicznemu. Animacja kultury tanecznej osób z niepełnosprawnością staje się przy tym edukacją $\mathrm{w}$ ujęciu ogólnospołecznym. Sprzyja bowiem rozbudzaniu wiedzy uwrażliwiając na potrzeby, kształtując krytyczne i kreatywne postawy wprowadza w świat jej znaczeń równocześnie na nie otwierając - co stanowi wymiar ewaluacyjny rozpatrywanych tu kierunków 
praktyki tanecznej. Tak rozumiana praktyka z udziałem animacji staje się podstawą przyjęcia prospektywnych, proosobowych i prohumanistycznych oddziaływań kultury tanecznej osób z niepełnosprawnością jako niezbędnego warunku postrzegania jej jako idei pedagogicznej.

\section{BIBLIOGRAFIA}

Besnard, P. (1988). Problematyka animacji społeczno-kulturalnej. W: M. Debesse, G. Mialaret (red.), Rozprawy o wychowaniu. 2. Warszawa: Wydawnictwo PWN.

Gajda, J. (red.), (1993). Wybrane problemy animacji kulturalnej. Animator - proces i formy animacji kulturalnej - efekty. Lublin: UMCS.

Gratiot-Alphandery H, (1977). Culture et animation socjo-culturelle. Cahiers de L'Animation, $17,1-2$.

Grzegorek, J.N. (2015). Inny w przestrzeni wychowania do twórczości - tancerz z niepełnosprawnością ruchową. W: Interdyscyplinarność w opiece i wsparciu osób niepetnosprawnych. Problemy edukacji, rehabilitacji i socjalizacji osób niepełnosprawnych, t 21 (2/2015), Katowice: Wydawnictwo Uniwersytetu Śląskiego.

Grzegorek, J.N. (2016). Somaestetyczne konteksty tańca współczesnego, czyli o trudnej sztuce tworzenia siebie przez taniec. W: Zeszyty Naukowe Forum Młodych Pedagogów przy Komitecie Nauk Pedagogicznych Polskiej Akademii Nauk, Zeszyt 2o. Warszawa: Wydawnictwo APS, 126-139.

Grzegorek, J.N. (2016). Animatorzy artystycznej kultury studenckiej w'środowisku akademickim. Typologia. Toruń: Wydawnictwo Adam Marszałek.

Grzegorek, J.N. (2019b). Kultura taneczna osób niepełnosprawnych. Próba zdefiniowania. W: Transdyscyplinarne studia o kulturze (i)edukacji. Rocznik Naukowy Kujawsko-Pomorskiej Szkoły Wyższej. Bydgoszcz: Wydawnictwo KPSW, 55-67.

Grzegorek, J.N. (2020). Dance Culture of Persons with Disabilities. An Attempt to Define the Phenomenon - Broadening the Meanings. Studia Choreologica, t. XXI. Poznań: Polskie Forum Choreologiczne.

Ingarden, R. (1972). Książeczka o człowieku. Kraków: Wydawnictwo Literackie.

Kłoskowska, A. (1981). Socjologia kultury. Warszawa: Wydawnictwo Naukowe PWN.

Kmita, J., Kostyrko, T. (1983). Elementy teorii kultury. Wykłady dla studentów kulturoznawstwa. Poznań: WNUAM.

Kopaliński, W. (2000). Słownik wyrazów obcych izwrotów obcojęzycznych zalmanachem. Warszawa: Klub Świat Książki.

Kopczyńska, M. (1993). Animacja społeczno-kulturalna: podstawowe pojęcia i zagadnienia. Warszawa: Centrum Animacji Kulturalnej.

Kostyrko, T. (1985). O kulturze artystycznej. Warszawa: Centralny Ośrodek Metodyki. Upowszechniania Kultury.

Lange, R. (1988). O istocie tańca i jego przejawach w kulturze. Perspektywa antropologiczna. Kraków: RHYTMOS.

Mioduszewska, A. (1979). Kształcenie animatorów kulturalnych we Francji. W: A. Gładysz (red.), Pedagogika Pracy Kulturalno-Oświatowej, t. 4. Katowice: Prace Naukowe Uniwersytetu Śląskiego.

Platon. (1958). Państwo. t. 1. Przeł. W. Witwicki. Warszawa: Wydawnictwo PWN.

Szczepański, J. (1980). Sprawy ludzkie. Warszawa: Czytelnik.

Znaniecki, F. (1937). Rola społeczna artysty. Wiedza i Życie, 8/9.

Znaniecki, F. (2008). Metoda socjologii. Warszawa: Wydawnictwo PWN.

Żebrowski, J. (1987). Zawód i osobowość animatora kultury w świetle nowych koncepcji wychowania zintegrowanego. Gdańsk: Wojewódzki Ośrodek Kultury. 


\section{SUMMARY}

\section{Dance Culture of People with Disabilities. Method or Animation?}

The article is devoted to the dance culture of people with disabilities from the perspective of its practice. It can be limited to internal activities and the implementation of dance creativity within the framework of artistic culture. It becomes important to justify the selection of methods of this practice based on the constitutive features of this culture and their individual dimensions: teleological, axiological, methodical and evaluation.

KEY WORDS: dance culture, animation, education, pedagogical idea 